\title{
A Direct Fourier Transform Infrared Spectroscopic Comparison of the Plasma- and Thermally-Driven Reaction of $\mathrm{CO}_{2}$ at Macor
}

\author{
P. A. Christensen ${ }^{1}$ Abd Halim Bin Md Ali ${ }^{1}$ Z. T. A. W. Mashhadani ${ }^{1}$ • \\ P. A. Martin ${ }^{2}$
}

Received: 8 November 2017/Accepted: 14 January 2018/Published online: 31 January 2018

(C) The Author(s) 2018. This article is an open access publication

\begin{abstract}
This paper reports the appraisal of two in situ Fourier Transform InfraRed plasma cells with respect to the interrogation of the glow of a non-thermal plasma (using a transmission cell), and the non-thermal plasma/solid (i.e. dielectric/catalyst) interface (with a reflectance cell). The paper also reports, for the first time, a direct comparison of the IR spectroscopy of plasmaand thermally-driven chemistry. The system chosen for study was the reduction of $\mathrm{CO}_{2}$ as there is a wealth of data in the literature for comparison. The catalyst was Macor, a ceramic material comprising primarily $\mathrm{Al}, \mathrm{Si}$ and $\mathrm{Mg}$ oxides. In both the thermal and plasma experiments, rotationally-excited $\mathrm{CO}_{2}\left(\mathrm{CO}_{2}^{*}\right)$ was observed: in the plasma system, rotationally-excited $\mathrm{CO}$ $\left(\mathrm{CO}^{*}\right)$ was produced via the reduction of $\mathrm{CO}_{2}$. Using the transmission cell, the conversion of $\mathrm{CO}_{2}$ to $\mathrm{CO}$ was estimated and found to be up to $9 \%$ at energy efficiencies of ca. 1-2\%, in line with the literature. No reaction of $\mathrm{CO}_{2}$ was observed in the thermal system. The data obtained using the reflectance cell were similar to those obtained with the transmission cell, with the minor differences reflecting the longer residence time and higher specific input energy. Interestingly, two plasma-induced bands were observed in the reflectance experiments which increased in intensity with time and input power: these may be due transverse and longitudinal optical modes of $\mathrm{SiO}_{2}$ and did not appear to participate in the observed chemistry.
\end{abstract}

Keywords Non-thermal plasma · In situ FTIR spectroscopy · Reflectance · Transmission · $\mathrm{CO}_{2}$ reduction

Electronic supplementary material The online version of this article (https://doi.org/10.1007/s11090-0189874-6) contains supplementary material, which is available to authorized users.

P. A. Christensen

paul.christensen@ncl.ac.uk

1 School of Engineering, Bedson Building, Newcastle University, Newcastle upon Tyne NE1 7RU, UK

2 School of Chemical Engineering and Analytical Science, The University of Manchester, Oxford Road, Manchester M13 9PL, UK 


\section{Introduction}

Non thermal plasma is produced by the partial ionization by electron impact of a gas using high $\mathrm{AC}$ or pulsed high voltages in the $\mathrm{kV}$ range. The temperature of the electrons in such plasmas are typically $10^{4}-10^{5} \mathrm{~K}$, whilst the heavier species such as the ions and gas molecules remain at temperatures around ambient. This generates radicals, ions and vibrationally and electronically excited species not normally present in thermal equilibrium at room temperature $[1,2]$. In principle, almost $97 \%$ of the plasma discharge power of low temperature plasmas can be converted into vibrational excitation of the gas feed molecules $[3,4]$. Adding a catalyst can speed up the chemical processes in a plasma and/or offer alternative mechanistic pathways with lower activation energies: thus, reactive species are produced and interact with catalyst at temperatures at which most thermally-driven process would be slow. Further, vibrationally excited molecules can have markedly different sticking probabilities and different chemistries on the surface of catalysts in contact with plasma [5] and it should be possible to enhance targeted reactions and suppress others by controlling the number density of electrons and electron and gas temperatures.

Inevitably, the first problem raised in any discussion of plasma-catalysis is low energy efficiency which is typically $\leq 10 \%$ for the reactor designs commonly employed (usually tube reactors) [6]. In the longer term energy efficiency should improve once plasma catalysis is more fully understood. In the short term, however, this low efficiency need not be a major obstacle: for example, matching the production of electricity from renewable energy to demand is very difficult, and often the surplus is simply spilled: the storage of this surplus energy chemically is seen as a possible solution to this problem, and the plasma-driven reduction of $\mathrm{CO}_{2}$ to $\mathrm{CO}$ and $\mathrm{O}_{2}$ is perceived as one possible chemical process, particularly as some industrial plants produce almost pure $\mathrm{CO}_{2}$ as waste gas [2, 7].

From the above discussion it is clear that, in principle, plasma-driven catalysed processes should open up wholly novel chemistries. However, progress has been slow, largely because catalyst selection appears to be based on those materials that are active for the analogous thermally-driven processes, and this may be due to the paucity of analytical information on non-thermal plasmas compared to, e.g. gas phase catalysis [1]. There are few analytical studies on the chemistry taking place actually in the glow of non-thermal plasmas, and these largely employ emission spectroscopy [8-10] or the detection of a single species [11]. There are a number of studies on the downstream analysis of the exhaust from NTPs, see for example [12], but actual studies of the plasma glow with, for example, IR spectroscopy [13] or of the catalyst surface in contact with a plasma is only a relatively recent phenomenon [14-18]. It is critical, if the potential of NTP is to be realized, that the identities of the reactive species on and near the catalysts surface are revealed [19]. In addition, there are no papers reporting direct comparison between thermal and plasma-driven catalyzed chemical conversions.

The aim of the work reported in this paper was to assess the efficacy of a combination of infrared reflectance and transmission spectroscopy to the study of non-thermal plasma and, in particular, the plasma/catalyst interface and to compare and contrast the data so obtained with the analogous thermally-driven process. The model system chosen was the reduction of $\mathrm{CO}_{2}$ to $\mathrm{CO}$ and $\mathrm{O}_{2}$. Macor was chosen as the dielectric for its reasonable dielectric constant, ca 6, and its stability over the temperature range of interest, 25-600 ${ }^{\circ} \mathrm{C}$ [20] rather than for any possible catalytic activity. 


\section{Experimental}

\section{The Non-thermal Plasma Infrared Cells}

The plasma transmission cell, see Fig. 1a, was designed and fabricated in-house and was made from a $15 \mathrm{~cm}$ long, cylindrical polytetrafluoroethylene (PTFE) tube with an outer diameter of $6.3 \mathrm{~cm}$ and an inner diameter of $2.5 \mathrm{~cm}$. The high voltage electrodes were in the form of two plungers, sealing against the inner walls of the PTFE via rubber ' $O$ ' rings. The plungers were hollow down their axes (a $4 \mathrm{~mm}$ diameter hole) and the feed gas was delivered via one of these channels. The electrodes were covered with $5 \mathrm{~mm}$ thick Macor caps [Goodfellow Cambridge: quartz (35-50\%), magnesium oxide (15-20\%), aluminium oxide (15-20\%) and fluoride (1-5\%)] fitted snugly over each disc electrode: one cap had a hole aligned with the central, gas delivery channel and gas exhaust was via a nozzle on the top of the cell. Two infrared transparent $\mathrm{CaF}_{2}$ windows $(25 \mathrm{~mm}$ diameter, $3 \mathrm{~mm}$ thick, Crystran) were glued into the PTFE cell. The distance between the windows (path length) was $5.1 \mathrm{~cm}$. The windows were positioned such that their centres aligned with the centre of the $5 \mathrm{~mm}$ gap between the electrodes. The plasma volume was $7.4 \mathrm{~cm}^{3}$ and the residence time at a flow rate of $200 \mathrm{~cm}^{3} \min ^{-1}$ was $2.2 \mathrm{~s}$.

The electrodes were connected to a NeonPro lamp transformer, NP100000-30 (Hyrite, China) which provided an output of $10 \mathrm{kV}$ at a constant frequency of $24 \mathrm{kHz}$. A voltage controller (Carroll \& Meynell) was used to control the input power to the HV transformers. The input power to the plasma was monitored using a Gadget 13A power meter, N67FU (Maplin, UK); the input powers employed (20-28 W) were those obtained by subtracting the input power observed with plasma to the reading obtained with the system switched on but with no plasma initiated $(4 \mathrm{~W})$.

The reflectance NTP cell is shown in Fig. $1 \mathrm{~b}$ : the IR beam passed through a $2 \mathrm{~mm} \mathrm{CaF}$ plate window and a $5 \mathrm{~mm}$ gap before being incident on the surface of a $3 \mathrm{~cm} \times 3 \mathrm{~cm} \times 0.5 \mathrm{~cm}$ Macor plate covered by a Ti mesh (50\% open area) electrode at an angle of $24^{\circ}$. The other electrode was a $2.3 \mathrm{~cm} \times 2.2 \mathrm{~cm} \times 0.007 \mathrm{~cm}$ stainless steel foil mounted on an alumina plate behind the Macor. The same power supply etc. was employed as for the transmission cell. In contrast to the transmission cell, the plasma was in contact with a titanium mesh electrode as well as Macor. The plasma volume was $2.0 \mathrm{~cm}^{3}$ and the residence time at a flow rate of $30 \mathrm{~cm}^{3} \mathrm{~min}^{-1}$ (the cell could not sustain high flow rates) was $4.0 \mathrm{~s}$.

For the transmission cell, the input powers of 20 and $28 \mathrm{~W}$ correspond to Specific Input Energies (SIEs) of 6.0 and $8.4 \mathrm{~kJ} \mathrm{dm}^{-3}$, respectively and defined as [21]:

$$
\mathrm{SIE}\left(\mathrm{kJ} \mathrm{dm}^{-3}\right)=\text { Discharge power }\left(\mathrm{kJ} \mathrm{s}^{-1}\right) / \text { Total gas flow rate }\left(\mathrm{dm}^{3}\right)
$$

Using the plasma reflectance cell, an input power of $24 \mathrm{~W}$ at a flow rate of $30 \mathrm{~cm}^{3} \mathrm{~min}^{-1}$ corresponds to an SIE of $48.0 \mathrm{~kJ} \mathrm{dm}^{-3}$.

The design of the transmission cell did not allow for cooling of the electrodes apart from the $200 \mathrm{~cm}^{3} \mathrm{~min}^{-1}$ flow of the feed gas: the reflectance cell had dedicated cooling channels for nitrogen gas, as shown in Fig. $1 \mathrm{~b}$.

\section{The Plasma FTIR System}

An Agilent FTS7000 FTIR spectrometer with a Deuterated TriGlycine Sulfate (DTGS) detector was employed. The IR beam was passed through the plasma via the two $\mathrm{CaF}_{2}$ 


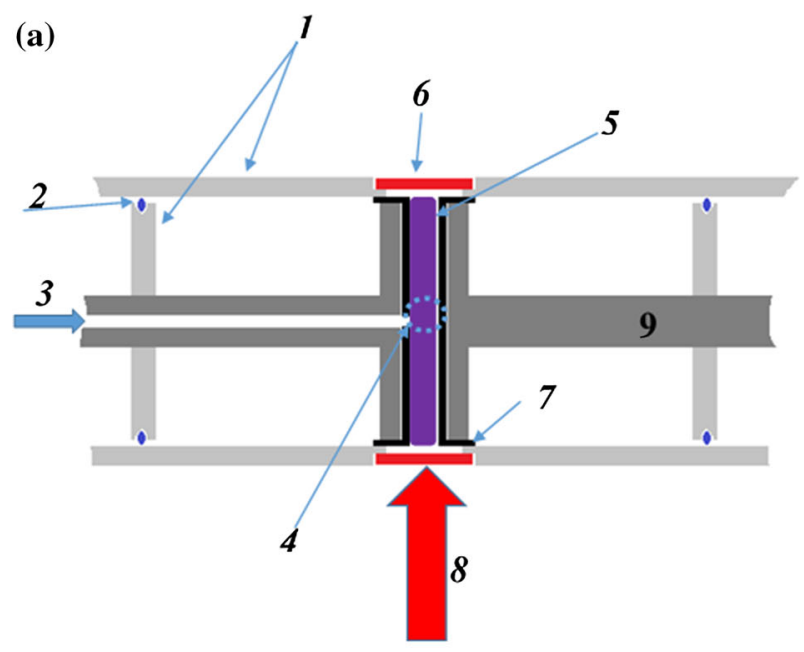

(b)

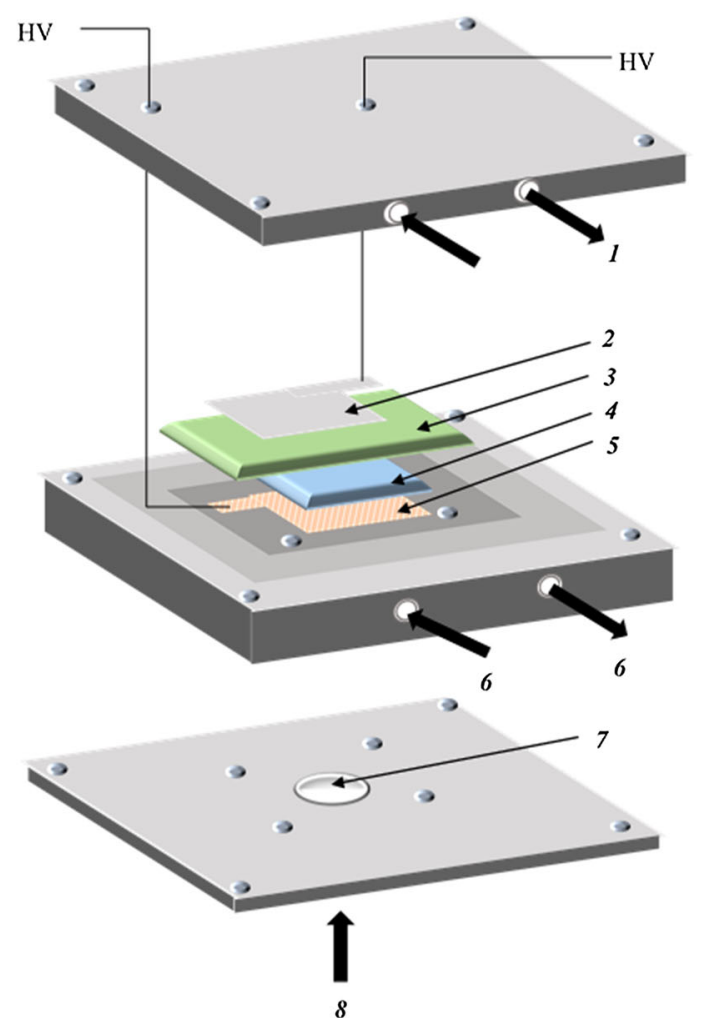

Fig. 1 The non-thermal plasma a transmission cell: 1 PTFE, 2 rubber "O" ring, 3 feed gas, 4 gas outlet, 5 plasma, $6 \mathrm{CaF}_{2}$ window, 7 Macor cap, $8 \mathrm{IR}$ beam, 9 steel electrode and $\mathbf{b}$ reflectance cell: 1 cooling gas, 2 stainless steel shim, $3 \mathrm{Al}_{2} \mathrm{O}_{3}$, 4 Macor, 5 titanium mesh, 6 feed gas, $7 \mathrm{CaF}_{2}$ window, 8 IR beam 
windows to the detector via an Amtir-1 filter, $25 \mathrm{~mm} \times 2 \mathrm{~mm}$ (Spectra-Tech, USA) to remove visible light.

$\mathrm{CO}_{2}(\mathrm{R} 744 / 100 \%)$ was supplied by BOC, UK and dinitrogen was obtained from a NITROSource generator. The gasses were mixed as appropriate and the composition controlled using flow meters. Table 1 summarizes the feed gas compositions employed in the work reported in this paper.

The cell was first flushed with $\mathrm{N}_{2}$ at a flowrate of $200 \mathrm{~cm}^{3} \mathrm{~min}^{-1}$ for $120 \mathrm{~min}$, and a single beam spectrum taken (100 co-added and averaged scans at $8 \mathrm{~cm}^{-1}$ resolution, $60 \mathrm{~s}$ per scan set), after which the $\mathrm{CO}_{2}+\mathrm{N}_{2}$ at a nominal composition of $10 \% \mathrm{CO}_{2}+90 \% \mathrm{~N}_{2}$ was admitted to the cell at a total flow rate of $200 \mathrm{~cm}^{3} \mathrm{~min}^{-1}$ and a second single beam spectrum collected, both without plasma. Sample spectra, $S_{S}$, were then taken every 2 min after the high voltage-power supply was switched on up to $20 \mathrm{~min}$. By using the first single beam (of the nitrogen gas with no plasma) as the reference spectrum $\left(S_{R}\right)$ all of the infrared active species present in the plasma were observed; using the second single beam as the reference spectrum resulted in difference spectra, showing only the changes incurred on initiating the plasma.

\section{The Thermal FTIR System}

Thermal in situ FTIR experiments were carried out using a Varian 670-IR spectrometer equipped with a ceramic air-cooled infrared source, a cooled DLaTGS detector and a Specac Environmental Chamber and diffuse reflectance unit [22]. A $12.5 \mathrm{~mm}$ diameter, $2 \mathrm{~mm}$ thick Macor disc was employed as the sample. The Specac reflectance accessory allows IR spectra to be collected under controlled atmosphere conditions from room temperature to $600^{\circ} \mathrm{C}$ and pressures from vacuum to 34 at. The IR beam is incident on the sample in the cell at angles from $20^{\circ}$ to $76^{\circ}$ with respect to the horizontal plane via a $\mathrm{ZnSe}$ window. The reference spectrum $\left(\mathrm{S}_{\mathrm{R}}, 8 \mathrm{~cm}^{-1}\right.$ resolution, 100 spectra per scan set, and 1 min per spectrum) was collected at $25{ }^{\circ} \mathrm{C}$ (see below) in the flowing $\mathrm{N}_{2}+\mathrm{CO}_{2}$, after which the environmental chamber was isolated from the gas supply and sample spectra $\left(\mathrm{S}_{\mathrm{S}}\right)$ were collected at $50{ }^{\circ} \mathrm{C}$, and at $50{ }^{\circ} \mathrm{C}$ intervals thereafter up to $600{ }^{\circ} \mathrm{C}$. The temperature was ramped at a rate of $5^{\circ} \mathrm{C} \min ^{-1}$.

\section{Data Manipulation}

The spectra obtained in the thermally-driven experiments, and plasma-driven experiments using the transmission cell are presented below as:

Table 1 The feed gas compositions employed in the plasma experiments reported in this paper

\begin{tabular}{ll}
\hline Input power $(\mathrm{W})$ & Feed gas composition $\mathrm{CO}_{2} \%, \mathrm{~N}_{2} \%(\mathrm{Ar})$ \\
\hline 14 & $9.7 / 90.3$ \\
20 & $12.7 / 87.3$ \\
20 & $100 / 0$ \\
22 & $11.7 / 88.3$ \\
24 & $13.3 / 86.7$ \\
26 & $12.2 / 87.8$ \\
28 & $12.2 / 87.8$ \\
$24 *$ & $31.1 / 68.9$ \\
\hline
\end{tabular}




$$
\text { Absorbance, } A=\log _{10}\left(\mathrm{~S}_{\mathrm{R}} / \mathrm{S}_{\mathrm{S}}\right)
$$

This results in difference spectra in which peaks pointing upwards (i.e. to + absorbance) represent a gain in absorbing species at $S_{S}$ with respect to $S_{R}$, and peaks pointing down (to - absorbance) represent the loss of absorbing species. There was significant reflection from the window of the reflectance cell, and hence the single beam spectrum of the $\mathrm{CaF}_{2}$ window was subtracted from single beam spectra $S_{S}$ and $S_{R}$ prior to the data manipulation in Eq. (2).

The concentrations of the various species observed in the plasma experiments were calculated using the Beer-Lambert law:

$$
A=\varepsilon c L
$$

where $\varepsilon$ is the molar decadic extinction coefficient $\left(\mathrm{M}^{-1} \mathrm{~cm}^{-1}\right), c=$ concentration $(\mathrm{M})$ and $L=$ optical path length $(\mathrm{cm})$.

\section{Extinction Coefficients}

The integrated extinction coefficient of $7.0 \times 10^{5} \mathrm{~cm} \mathrm{~mol}^{-1}$ reported by Bolis and coworkers [23] was employed for the $\mathrm{CO}$ absorption between 2002 and $2225 \mathrm{~cm}^{-1}$ : our methodology was checked by determining the extinction coefficient of $\mathrm{CO}$ using a $1 \mathrm{~cm}$ pathlength transmission cell with $100 \% \mathrm{CO}$ at $24{ }^{\circ} \mathrm{C}$, and the value so obtained compared to that of Bolis et al. and found to be within $10 \%$. The same cell was employed to determine the integrated extinction coefficient of the combination bands of $\mathrm{CO}_{2}$ (see below) between 3491 and $3769 \mathrm{~cm}^{-1}$, and this was found to be $6.5 \times 10^{5} \mathrm{~cm} \mathrm{~mol}^{-1}$. Using the thermal FTIR system and a static atmosphere of $3.7 \% \mathrm{CO}_{2}+96.3 \% \mathrm{~N}_{2}$, the integrated extinction coefficient of the $\mathrm{CO}_{2}$ combination bands was found to remain constant over the temperature range from 25 to $150{ }^{\circ} \mathrm{C}$ of interest in this work.

\section{Energy and Conversion Efficiency}

In the plasma experiments, the conversion of $\mathrm{CO}_{2}$ to rotationally-excited $\mathrm{CO}$ is:

$$
\% \mathrm{CO}^{*}=100 \times\left[\mathrm{CO}^{*}\right]_{\text {glow }} /\left[\mathrm{CO}_{2}\right]_{\text {feed }}
$$

where $\left[\mathrm{CO}_{2}\right]_{\text {feed }}$ is the concentration of $\mathrm{CO}_{2}$ in the feed to the plasma cell and $[\mathrm{CO} *]_{\text {glow }}$ is the concentration of $\mathrm{CO}$ in the plasma glow. The corresponding $\mathrm{CO}$ selectivity, $\% \mathrm{~S}_{\mathrm{CO}} *$ is:

$$
\% \mathrm{~S}_{\mathrm{CO}^{*}}=100 \times\left[\mathrm{CO}^{*}\right]_{\text {glow }} /\left(\left[\mathrm{CO}_{2}\right]_{\text {feed }}-\left[\mathrm{CO}_{2}^{*}\right]_{\text {glow }}\right)
$$

The carbon balance, $\% \mathrm{C}$, is:

$$
\% \mathrm{C}=100 \times\left(\left[\mathrm{CO}^{*}\right]_{\text {glow }}+\left[\mathrm{CO}_{2}^{*}\right]_{\text {glow }}\right) /\left[\mathrm{CO}_{2}\right]_{\text {feed }}
$$

The energy efficiency for the production of $\mathrm{CO}$ is:

$$
\eta_{\mathrm{CO}} / \%=100 \Delta \mathrm{H} / E_{p, I}
$$

where $\Delta \mathrm{H}$ is the enthalpy $\left(279.8 \mathrm{~kJ} \mathrm{~mol}^{-1}\right)$ of the process [7]: 


$$
\mathrm{CO}_{2} \rightarrow \mathrm{CO}+1 / 2 \mathrm{O}_{2}
$$

at $300 \mathrm{~K} . E_{p, \mathrm{CO}}$ is the energy expended in producing $1 \mathrm{~mol}$ of $\mathrm{CO}$ and assuming that the IR spectra record an average picture over the 1 min data collection time.

All the calculations presented below are based on the integrated areas of the $\mathrm{CO}_{2}$ and $\mathrm{CO}_{2}^{*}$ combination bands and the $\mathrm{P}$ and $\mathrm{R}$ branches of the $\mathrm{CO}^{*}$ absorption. These are all subject to inevitable experimental error, particularly with respect to determining baselines: this is particularly relevant to the determination of the integrated absorptions of the $\mathrm{CO}^{*}$ features as these are adjacent to the very strong $\mathrm{CO}_{2}^{*}$ fundamental. For the experiments employing the transmission cell, the estimated error in the baseline calculations of the $\mathrm{CO}^{*}$ bands, i.e. between employing a linear versus curved baseline between the extremes of the spectral ranges employed, was ca. 10\%. The experimental error associated with the plasma reflectance cell was higher as the optical pathlength could not be measured directly (as was the case with the transmission cell) but was determined from calculations based on the optical configuration and the integrated intensity of the $\mathrm{CO}_{2}$ combination bands of $100 \%$ $\mathrm{CO}_{2}$. On this basis, the pathlength of the reflectance cell was ca. five times lower than that of the transmission cell $(5.1 \mathrm{~cm}$ cff. ca. $1 \mathrm{~cm})$ making baseline correction even less accurate due to the weaker $\mathrm{CO}$ absorptions.

\section{Results and Discussion}

\section{The Plasma-Driven Reaction of $\mathrm{CO}_{2}$ at Macor}

\section{Plasma Transmission Cell}

Considering first the data obtained using $\mathrm{CO}_{2}+\mathrm{N}_{2}$, Fig. $\mathrm{S} 1$ shows a single beam spectrum of the plasma transmission cell at $25^{\circ} \mathrm{C}$ with flowing $12.2 \% \mathrm{CO}_{2}+87.8 \% \mathrm{~N}_{2}$ and no plasma. The $\mathrm{P}$ and $\mathrm{R}$ asymmetric stretch $\left(\mathrm{v}_{3}\right)$ bands of $\mathrm{CO}_{2}$ at 2340 and $2360 \mathrm{~cm}^{-1}$ [24-26] are clearly saturated. The small feature around $2260 \mathrm{~cm}^{-1}$ may be attributed to the ${ }^{13} \mathrm{C}^{16} \mathrm{O}_{2}$ fundamental [26]. The features between 3500 and $4000 \mathrm{~cm}^{-1}$ are attributable to $\mathrm{CO}_{2}$ combination bands [27].

Figure 2a shows selected spectra collected as a function of time at $28 \mathrm{~W}$ input power employing the spectrum collected using nitrogen gas as the reference. The experiment in the figure was repeated at input powers of $20,22,24$ and $26 \mathrm{~W}$, with no additional bands being observed.

The saturating gain feature in Fig. 2a between 2250 and $2400 \mathrm{~cm}^{-1}$ is in the region of the $\mathrm{P}$ and $\mathrm{R}$ bands of the $\mathrm{CO}_{2}$ asymmetric stretch. However, Fig. S2(a) shows the $\mathrm{CO}_{2} \mathrm{v}_{3}$ region of the spectra collected after $20 \mathrm{~min}$ in Fig. 2a, and the spectrum collected in the same experiment before the plasma was initiated: as can be seen, the spectra collected with plasma are somewhat broader than that collected without. Fig. S2(b) shows the analogous spectrum of the $\mathrm{CO}_{2}$ combination band region after 20 min operation and that without plasma: although the intensities of the combination bands decreased on application of the plasma, it is clear that the bands are broadened. Given that the molecules present in the non-thermal plasma are at thermal equilibrium but the electrons are at a much higher temperature, then the spectra in Fig. 2a, S2(a) and S2(b) suggest that any $\mathrm{CO}_{2}$ present in the plasma is rotationally excited [13], and that this species is responsible for the combination and asymmetric stretch features in Fig. 2a. Figure $2 \mathrm{~b}$ shows the spectrum collected after 20 min in Fig. 2a using as the reference the single beam spectrum collected of 
Fig. 2 a In situ FTIR spectra $\left(8 \mathrm{~cm}^{-1}\right.$ resolution, 100 co-added and averaged scans, $60 \mathrm{~s}$ per scan set) collected at the times shown on the figure at an input power of $28 \mathrm{~W}$. The gas composition was $12.2 \% \mathrm{CO}_{2}+87.8 \% \mathrm{~N}_{2}$ and the reference spectrum was that taken with no plasma and a $\mathrm{N}_{2}$ gas feed. b The spectrum collected after $20 \mathrm{~min}$ in a using the spectrum collected with no plasma and the $12.2 \%$ $\mathrm{CO}_{2}+87.8 \% \mathrm{~N}_{2}$ feed gas as reference
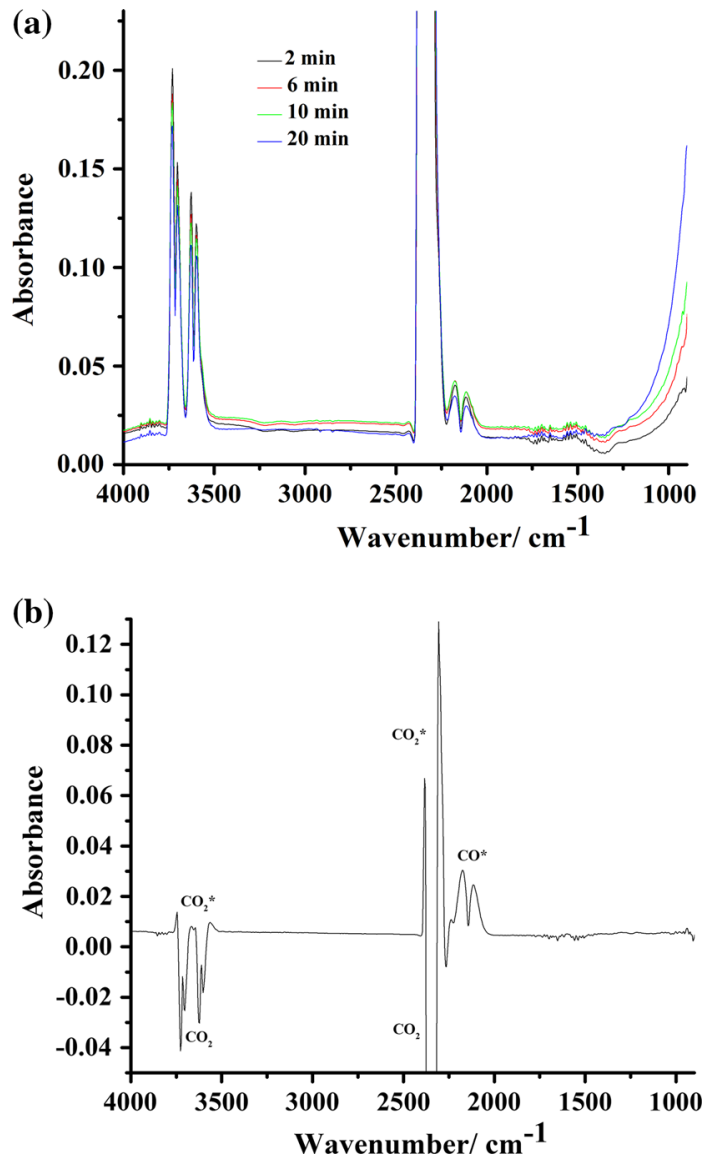

the $\mathrm{CO}_{2} / \mathrm{N}_{2}$ feed with no plasma: the $\mathrm{CO}^{*}$ bands are very clear, as are the structures between 2200 and $2400 \mathrm{~cm}^{-1}$ and 3500 and $3800 \mathrm{~cm}^{-1}$ due to the loss of ground state $\mathrm{CO}_{2}$ bands superimposed upon the $\mathrm{CO}_{2}^{*}$ gain features. The features between 2200 and $2400 \mathrm{~cm}^{-1}$ in Fig. 2b were modelled using Spectralcalc and Origin and the difference spectrum obtained by subtracting the spectrum of $\mathrm{CO}_{2}$ at room temperature from that of the excited $\mathrm{CO}_{2}$ at $396 \mathrm{~K}$ are shown in Fig. S2(c): the figure supports the assignment of the gain features in Fig. 2a to higher temperature, rotationally excited $\mathrm{CO}_{2}\left(\mathrm{CO}_{2}^{*}\right)$. This assignment was further supported by the behaviour of the $\mathrm{CO}$ absorption in the plasma experiments and the thermal experiment, see below.

From Fig. 2a and S2(a) it is apparent that there are clear gain features due to the $\mathrm{P}$ and $\mathrm{R}$ bands of CO near 2116 and $2176 \mathrm{~cm}^{-1}[25,28]$ and these are due to the higher temperature, rotationally excited gas, as may be expected from the discussion above. Thus, Fig. S3 shows the spectra collected after 2 and $20 \mathrm{~min}$ in the experiment in Fig. 2a, using the spectrum collected with the same gas feed but without plasma as the reference (see below) with a spectrum of $\mathrm{CO}$ gas in a $1 \mathrm{~cm}$ pathlength transmission cell at room temperature. The $\mathrm{CO}$ and 2 min spectra were scaled down to allow comparison. As may be seen from the figure, the $\mathrm{CO}$ bands in the spectra collected during the plasma experiment are somewhat broader than those of the room temperature $\mathrm{CO}$, and the $\mathrm{P}$ and $\mathrm{R}$ maxima 
move apart as would be expected for $\mathrm{CO}$ if the molecule was rotationally excited $\left(\mathrm{CO}^{*}\right)$ : for example, Bauerecker et al. [29] observed the rotation-vibration bandwidth of ${ }^{13} \mathrm{C}^{16} \mathrm{O}$ to be reduced by about $40 \%$ on cooling the gas from 300 to $45 \mathrm{~K}$, without any change in band centre. The resolution of the spectra obtained in the experiments reported in this paper $\left(8 \mathrm{~cm}^{-1}\right)$ was chosen as the highest possible allowing for a reasonable data collection time. However, temperature calculations based on the maxima of the P and R branches of $\mathrm{CO}$ [30] gave wide ranges when the resolution was taken into account: e.g. allowing $\pm 4 \mathrm{~cm}^{-1}$ for $\mathrm{P}$ and $\mathrm{R}$ branches nominally at 2172 and $2118 \mathrm{~cm}^{-1}$ resulted in temperatures between 210 and $382 \mathrm{~K}$. Hence, in order to allow comparison within the data sets, ambient temperature was employed.

The vibrationally excited form of the ground electronic state of $\mathrm{CO}_{2}, \mathrm{CO}_{2}^{*}\left({ }^{1} \Sigma^{+}\right)$, is generally accepted as being the intermediate in the plasma-induced reduction of $\mathrm{CO}_{2}$ to $\mathrm{CO}$ and $\mathrm{O}_{2}$ for plasmas with lower mean electron energies than those in dielectric barrier discharges [3]. This is clearly not the same species as the rotationally-excited $\mathrm{CO}_{2}^{*}$ observed in Fig. 2. $\mathrm{CO}_{2}^{*}\left({ }^{1} \Sigma^{+}\right)$may be formed directly through collisions with electrons in the plasma [31, 32]:

$$
\mathrm{CO}_{2}+\mathrm{e}^{-} \rightarrow \mathrm{CO}_{2}^{*}\left({ }^{1} \Sigma^{+}\right)+\mathrm{e}^{-}
$$

or via collisional energy transfer from vibrationally excited species such as $\mathrm{N}_{2}^{*}\left({ }^{1} \Sigma^{+}\right)$[31]:

$$
\mathrm{CO}_{2}+\mathrm{N}_{2}^{*}\left({ }^{1} \Sigma^{+}\right) \rightarrow \mathrm{CO}_{2}^{*}\left({ }^{1} \Sigma^{+}\right)+\mathrm{N}_{2}
$$

whilst $\mathrm{CO}_{2}^{*}\left({ }^{1} \Sigma^{+}\right)$decay can take place through relaxation to $\mathrm{CO}_{2}$ and photon emission or dissociation into $\mathrm{CO}$ and atomic oxygen $[26,27]$ :

$$
\begin{gathered}
\mathrm{CO}_{2}^{*}\left({ }^{1} \Sigma^{+}\right) \rightarrow \mathrm{CO}+\mathrm{O} \\
\mathrm{O}+\mathrm{O} \rightarrow \mathrm{O}_{2}
\end{gathered}
$$

The dissociation of $\mathrm{CO}_{2}$ via reaction (10) can take place by two possible routes [3, 33]: (1) excitation to vibrational levels of the ground excited state of $\mathrm{CO}_{2}$ which exceed the energy of the dissociation threshold: this results in ground state $\mathrm{CO}$ and singlet oxygen:

$$
\mathrm{CO}_{2}^{*}\left({ }^{1} \Sigma^{+}\right) \rightarrow \mathrm{CO}+\mathrm{O}\left({ }^{1} \mathrm{D}\right)
$$

(2) excitation to the first excited triplet state of $\mathrm{CO}_{2}$ via intersystem crossing resulting in ground state $\mathrm{CO}$ and ground state atomic oxygen.

$$
\mathrm{CO}_{2}^{*}\left({ }^{1} \Sigma^{+}\right)+\mathrm{e}^{-} \rightarrow \mathrm{CO}_{2}^{*}\left({ }^{3} \mathrm{~B}_{2}\right)+\mathrm{e}^{-} \rightarrow \mathrm{CO}+\mathrm{O}\left({ }^{3} \mathrm{P}\right)+\mathrm{e}^{-}
$$

The latter is favoured due to the non-adiabatic intersystem crossing and the reduction in the energy required for dissociation $[34,35]$. In $\mathrm{CO}_{2}$ feeds diluted with nitrogen, Snoeckx et al. [6] postulate that the dissociation of $\mathrm{CO}_{2}$ depends upon the partial pressure of $\mathrm{N}_{2}$ : thus, at low nitrogen pressure, the main reaction is the direct electron excitation of $\mathrm{CO}_{2}$ and subsequent reduction to $\mathrm{CO}$ and $\mathrm{O}_{2}$, as discussed above. In contrast, at high nitrogen partial pressure it is:

$$
\mathrm{CO}_{2}+\mathrm{N}_{2}\left(\mathrm{~A}^{3} \Sigma_{\mathrm{u}}^{+}\right) \rightarrow \mathrm{CO}+\mathrm{O}+\mathrm{N}_{2}
$$

In other words, as the partial pressure of nitrogen increases, the electron energy is primarily employed to excite the nitrogen molecules to the metastable $\mathrm{A}^{3} \Sigma_{\mathrm{u}}^{+}$state rather 
than for direct electron excitation of $\mathrm{CO}_{2}$, which may be the reason vibrationally excited $\mathrm{CO}_{2}$ was not detected in our experiments.

The integrated absorption intensities of the $\mathrm{CO}_{2}$ combination bands and the $\mathrm{CO}$ fundamental were employed to gain some quantitative insight into the chemistry of the plasma glow, and the results are summarized in Table 2. In general, the concentrations of both $\mathrm{CO}^{*}$ and $\mathrm{CO}_{2}^{*}$ declined with time at all input powers, leading to a loss in carbon inventory, as is shown in Table 2 and by the typical data (from the experiment in Fig. 2a) in Fig. 3 in which the integrated intensities of the $\mathrm{CO}^{*}$ and $\mathrm{CO}_{2}^{*}$ bands were normalized to their maximum values and plotted with respect to time: the raw data are shown in Fig. S4. The broadening of the $\mathrm{CO}_{2}$ and $\mathrm{CO}$ features suggests the decline in the concentration of $\mathrm{CO}^{*}$ is accompanied by a concomitant increase in the temperature of the gases in the plasma, and the two appear to be linked. The chemical simplicity of the plasma system and lack of any additional product absorptions suggests that there is a process, or processes, taking place leading to carbon-containing products that are infrared inactive or present at steady-state concentrations below the detection limit of the FTIR system. One example of the former is the Boudard reaction [36], which is commonly observed in plasma systems involving $\mathrm{CO} /$ $\mathrm{CO}_{2}$ :

$$
2 \mathrm{CO} \leftrightarrow \mathrm{C}+\mathrm{CO}_{2} \quad \Delta \mathrm{H}^{0}(298 \mathrm{~K})=-172 \mathrm{~kJ} \mathrm{~mol}^{-1}
$$

No carbon deposits were observed on the walls or windows of the cell, but these could have been swept away by the feed gas. As was stated above, the plasma temperature increased with operational time and input power: due to the exothermicity of reaction (15) and its negative reaction entropy, the equilibrium constant for the process decreases with temperature, and hence less loss of $\mathrm{CO}$ due to the Boudouard reaction would be expected with time, in contrast to the observed results.

As can be seen from Table 2, the conversion of $\mathrm{CO}_{2}$ to $\mathrm{CO}$ after 2 min was ca. $10-11 \%$ irrespective of the input power, declining with time, as expected on the basis of Fig. 3 and S4. The former observation was unexpected as an increase in conversion with increasing plasma power would be qualitatively expected on the basis of an increasing frequency of electron/gas collisions due to an increase in the discharge current $\left(I=P / V_{0}\right)$, as shown by Manley's equation [37]:

$$
P=4 f C_{d} V_{o}\left(V-V_{o} C_{g} / C\right)
$$

where $P$ is the discharge power $(\mathrm{W}), V_{o}$ is the discharge onset voltage $(\mathrm{kV}), V$ is the discharge voltage $(\mathrm{kV}), C_{g}$ is the capacitance of the background gas within the discharge gap $(\mathrm{F}), C$ is the total capacitance of the dielectric and gas $(\mathrm{F}), \varepsilon_{r}$ is the dielectric constant, $\varepsilon_{o}$ is vacuum permittivity $\left(8.854 \times 10^{-12} \mathrm{~F} \mathrm{~m}^{-1}\right), A$ and $d$ are the dielectric surface area $\left(\mathrm{m}^{2}\right)$ and thickness $(\mathrm{m})$, respectively.

The IR plasma cell was in no way optimised for energy efficient operation, but a comparison of the energy efficiency for, for example, $\mathrm{CO}$ production with the literature values would at the least give confidence that the plasma system under study was not atypical, and this was confirmed. Thus Table 2 shows the values of $\eta_{\mathrm{CO}}$ observed during the various experiments. As may be seen from the table, the energy efficiency of $\mathrm{CO}$ production decreased with increasing operational time and increasing input power: e.g. at $20 \mathrm{~W}$ the $\eta_{\mathrm{CO}}$ declined from $2.4 \%$ after 2 min to $1.9 \%$ after $20 \mathrm{~min}$, with the analogous values of $1.8-1.1 \%$ at $28 \mathrm{~W}$. Overall, the efficiency for $\mathrm{CO}$ production were broadly comparable to those reported in the literature, i.e. ca. $1-2 \%[6,7,38,39]$. 
Table 2 Summary of the data obtained in the experiments typified by Fig. 1a

\begin{tabular}{|c|c|c|c|c|c|c|c|c|}
\hline $\begin{array}{l}\text { Input power } \\
\text { (W) }\end{array}$ & $\begin{array}{l}\text { Time } \\
\text { (Min) }\end{array}$ & $\begin{array}{l}{\left[\mathrm{CO}_{2}\right]_{\text {feed }}} \\
\left(10^{-3} \mathrm{M}\right)\end{array}$ & $\begin{array}{l}{\left[\mathrm{CO}_{2}^{*}\right]_{\text {glow }}} \\
\left(10^{-3} \mathrm{M}\right)\end{array}$ & $\begin{array}{l}{[\mathrm{CO} *]_{\text {glow }}} \\
\left(10^{-4} \mathrm{M}\right)\end{array}$ & $\% \mathrm{CO}^{*}$ & $\begin{array}{l}\eta_{\mathrm{CO}} \\
(\%)\end{array}$ & $\begin{array}{l}\mathrm{S}_{\mathrm{CO}} * \\
(\%)\end{array}$ & $\% \mathrm{C}$ \\
\hline \multirow[t]{5}{*}{20} & 2 & 5.2 & 4.7 & 5.1 & 9.9 & 2.4 & 102.0 & 100.0 \\
\hline & 6 & & 4.6 & 4.9 & 9.4 & 2.3 & 80.6 & 97.7 \\
\hline & 10 & & 4.5 & 4.6 & 8.8 & 2.1 & 66.9 & 95.6 \\
\hline & 20 & & 4.4 & 4.1 & 7.9 & 1.9 & 54.6 & 93.4 \\
\hline & & & & & & & - & \\
\hline \multirow[t]{5}{*}{22} & 2 & 4.8 & 4.3 & 4.3 & 10.2 & 2.1 & 96.5 & 99.6 \\
\hline & 6 & & 4.1 & 4.1 & 9.3 & 1.9 & 70.2 & 96.0 \\
\hline & 10 & & 4.1 & 4.1 & 8.7 & 1.8 & 59.4 & 94.1 \\
\hline & 20 & & 4.0 & 4.0 & 7.8 & 1.6 & 50.3 & 92.3 \\
\hline & & & & & & & - & \\
\hline \multirow[t]{5}{*}{24} & 2 & 5.4 & 4.9 & 5.1 & 9.4 & 2.0 & 89.7 & 98.9 \\
\hline & 6 & & 4.7 & 4.5 & 8.3 & 1.8 & 60.4 & 94.5 \\
\hline & 10 & & 4.6 & 4.2 & 7.6 & 1.6 & 51.1 & 92.7 \\
\hline & 20 & & 4.6 & 3.7 & 6.7 & 1.4 & 42.1 & 90.7 \\
\hline & & & & & & & - & \\
\hline \multirow[t]{5}{*}{26} & 2 & 5.0 & 4.4 & 5.3 & 10.7 & 1.9 & 92.2 & 99.2 \\
\hline & 6 & & 4.2 & 4.5 & 9.1 & 1.6 & 62.2 & 94.5 \\
\hline & 10 & & 4.2 & 4.1 & 8.2 & 1.5 & 49.8 & 91.8 \\
\hline & 20 & & 4.1 & 3.5 & 7.0 & 1.2 & 39.7 & 89.4 \\
\hline & & & & & & & - & \\
\hline \multirow[t]{4}{*}{28} & 2 & 5.0 & 4.3 & 5.3 & 10.7 & 1.8 & 75.9 & 96.6 \\
\hline & 6 & & 4.1 & 4.5 & 9.1 & 1.5 & 50.5 & 91.1 \\
\hline & 10 & & 4.0 & 4.0 & 8.1 & 1.3 & 42.3 & 88.9 \\
\hline & 20 & & 4.0 & 3.4 & 6.8 & 1.1 & 33.7 & 86.7 \\
\hline \multirow{4}{*}{$\begin{array}{c}20(100 \% \\
\left.\mathrm{CO}_{2}\right)^{\neq}\end{array}$} & 2 & 40.8 & - & 14.1 & 3.5 & 6.6 & & - \\
\hline & 6 & & - & 13.0 & 3.2 & 6.0 & & - \\
\hline & 10 & & - & 11.8 & 2.9 & 5.5 & & - \\
\hline & 20 & & - & 9.8 & 2.4 & 4.6 & & - \\
\hline \multirow{4}{*}{$\begin{array}{c}24(100 \% \\
\left.\mathrm{CO}_{2}\right)^{\neq}\end{array}$} & 2 & 40.8 & - & & & & & - \\
\hline & 6 & & - & & & & & - \\
\hline & 10 & & - & & & & & - \\
\hline & 20 & & - & & & & & - \\
\hline \multirow[t]{4}{*}{$14(\mathrm{Ar})$} & 2 & 4.4 & 3.9 & 4.6 & 10.3 & 3.1 & 90.4 & 98.9 \\
\hline & 6 & & 3.8 & 4.2 & 9.5 & 2.8 & 68.3 & 95.6 \\
\hline & 10 & & 3.8 & 4.0 & 8.9 & 2.6 & 57.3 & 93.4 \\
\hline & 20 & & 3.7 & 3.4 & 7.7 & 2.3 & 43.9 & 90.2 \\
\hline
\end{tabular}

${ }^{\neq} \mathrm{CO}_{2}$ and $\mathrm{CO}_{2}^{*}$ absorptions were saturated, rendering calculation of their concentrations etc. not feasible 
Fig. 3 Plots of the integrated absorbances of the $\mathrm{CO}^{*}$ and $\mathrm{CO}_{2}^{*}$ combination bands in Fig. $2 \mathrm{a}$ as a function of time. The plots were normalised to their maximum values

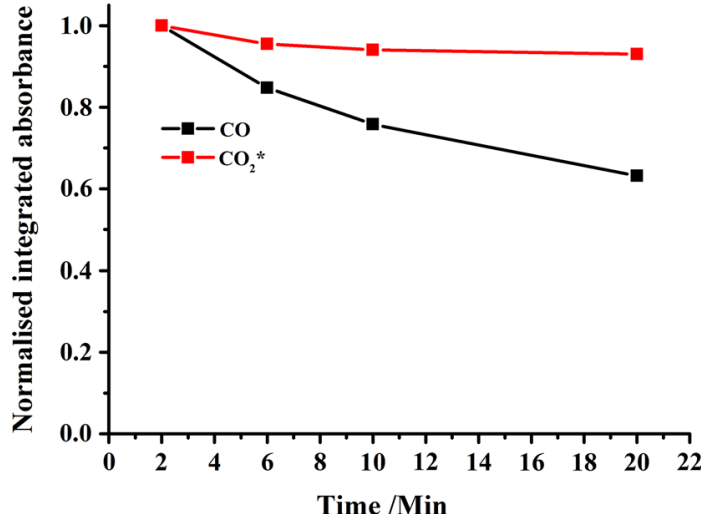

Table 2 also summarizes the data obtained using $100 \% \mathrm{CO}_{2}$ and $\mathrm{CO}_{2}+$ Ar. With respect to the former, it can be seen that, whilst the increase in $\mathrm{CO}_{2}$ results in an increase in the absolute amount of $\mathrm{CO}$ produced and the energy efficiency as would be expected, the fraction of $\mathrm{CO}_{2}$ converted to $\mathrm{CO}$ decreases, from ca. $10 \%$ after 2 min to ca. 6-7\%. These data support the positive role of $\mathrm{N}_{2}$ in terms of its direct involvement in the reduction of $\mathrm{CO}_{2}$, see (8)-(14) as well as the data obtained using Ar, see Table 2, where comparable conversion and energy efficiencies to those obtained using $\mathrm{CO}_{2}+\mathrm{N}_{2}$ were obtained but at significantly lower input energy and ca. $20 \%$ lower $\mathrm{CO}_{2}$ in the feed gas. Further, adding $\mathrm{N}_{2}$ or Ar is generally reported as rendering plasmas easier to ignite and having significant effect upon electron energy distribution functions [40].

\section{Plasma Reflectance Cell}

Figure $4 \mathrm{a}$ shows selected sample spectra collected at an input power of $24 \mathrm{~W}$ and a nitrogen flow rate of $30 \mathrm{~cm}^{3} \mathrm{~min}^{-1}$ using the plasma reflectance cell. The spectrum collected immediately before the plasma was initiated was employed as the reference and sample spectra were collected every 2-20 min after the plasma was turned on.

As may be seen from the figure, the spectra are featureless apart from two strong bands at 1210 (broad) and $1150 \mathrm{~cm}^{-1}$, that increase in intensity steadily with time. Fig. S5 shows plots of the integrated absorptions of the two bands obtained from analogous experiments to that in Fig. 4a as a function of input power from the spectra taken after 20 min operation: clearly, the features also increase in intensity with input power.

Figure $4 \mathrm{~b}$ shows the single beam spectra corresponding to the absorbance spectra in Fig. 4a along with the reference spectrum collected immediately before the plasma was initiated. As can be seen from the figure, the 1150 and $1210 \mathrm{~cm}^{-1}$ features were present before the plasma was initiated and simply increase in intensity as the plasma is turned on and with time thereafter: this suggests that the features have their origin in the oxides on the surface of the Macor and/or Ti mesh. Interestingly, however, these features were not observed in the reflectance spectra of unused Macor + Ti mesh, suggesting they appeared in the presence of plasma in a previous experiment to that in Fig. $4 \mathrm{~b}$ and had not completely relaxed by the time the latter commenced.

Figure 5 shows a repeat of the experiment in Fig. 4, using a feed gas composition of $49 \% \mathrm{CO}_{2}+51 \% \mathrm{~N}_{2}$. In addition to the features due to $\mathrm{CO}^{*}$ and $\mathrm{CO}_{2}^{*}$, the bands at 1150 and $1210 \mathrm{~cm}^{-1}$ are also present, and again grow with operational time. 
Fig. 4 a In situ FTIR spectra $\left(8 \mathrm{~cm}^{-1}\right.$ resolution, 100 co-added and averaged scans, $60 \mathrm{~s}$ per scanset) collected at the times shown on the figure at an input power of $24 \mathrm{~W}$ using the reflectance cell and nitrogen gas as the feed gas. The spectrum plasma was initiated was employed as the reference. b The single beam spectra from the experiment in a collected immediately before the
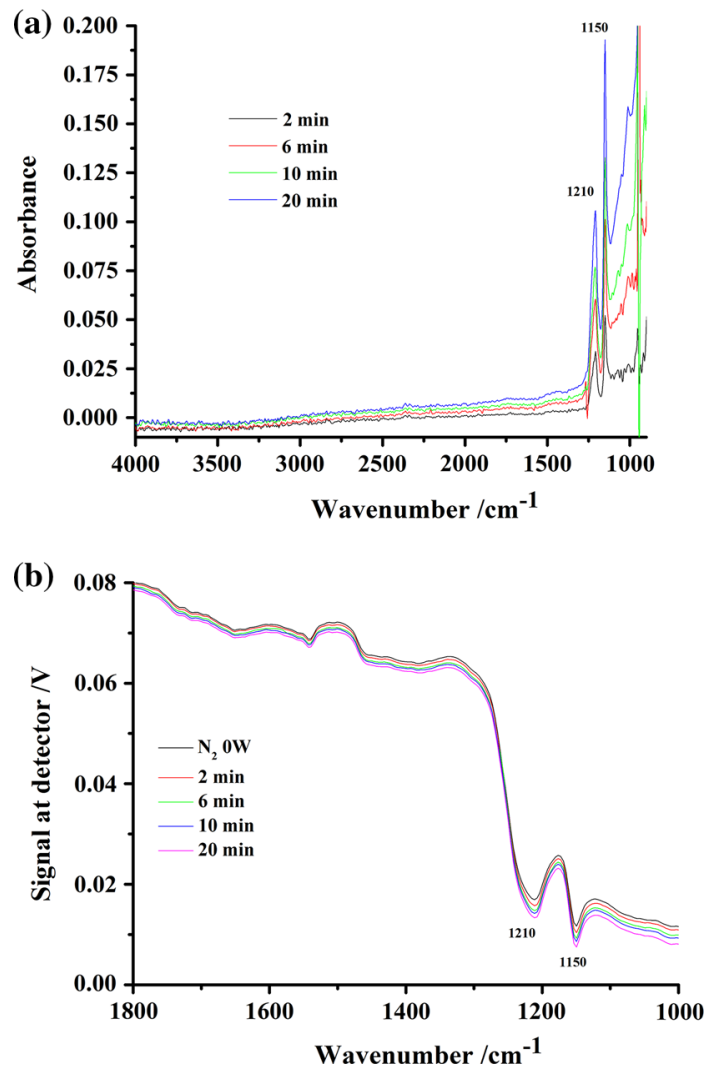

Fig. 5 In situ FTIR spectra $\left(8 \mathrm{~cm}^{-1}\right.$ resolution, 100 co-added and averaged scans, $60 \mathrm{~s}$ per scanset) collected at the times shown on the figure at an input power of $24 \mathrm{~W}$ using the reflectance cell and $49 \%$ $\mathrm{CO}_{2}+51 \% \mathrm{~N}_{2}$ as the feed gas. The spectrum collected immediately before the plasma was initiated was employed as the reference

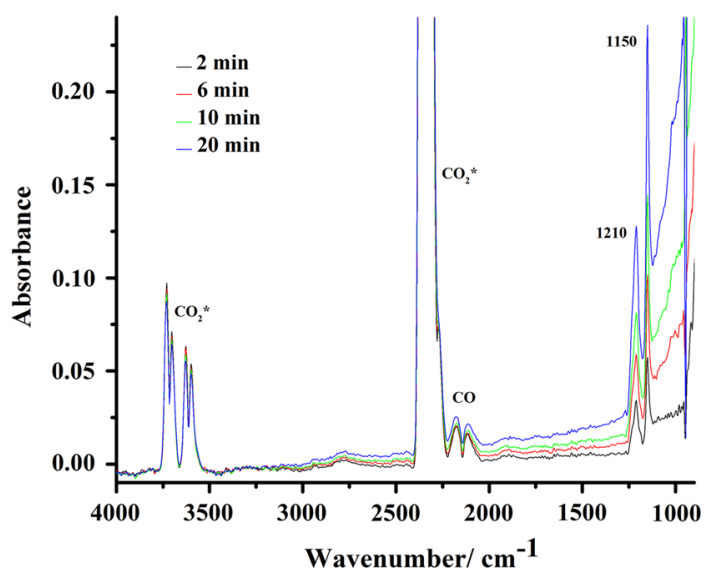

Fig. S6 shows plots of the normalised integrated absorptions of these features, and that of the $v_{3} \mathrm{CO}_{2}$ asymmetric stretch, as a function of time after the plasma was switched off and the cell flushed with nitrogen. The absorptions were normalised to their values after 2 min flushing, to aid comparison. The absorptions of the two features do not track the $\mathrm{CO}_{2}$ absorption, and the latter declines more rapidly: this suggests that the 1150 and $1210 \mathrm{~cm}^{-1}$ 
bands are not due to a gas-phase species (as, perhaps, may be expected from the fact that they were not observed in the transmission cell experiments discussed above, although the presence of the Ti mesh is an additional factor in the reflectance experiments). The relatively slow 'relaxation' of these bands argues against their being due to some form of electric field enhancement of the Ti-O bonds on the mesh or the metal-oxygen bonds of the Macor, as such would be expected to relax as soon as the field was removed. In addition, the features also appeared in experiments where $\mathrm{N}_{2}$ was replaced by argon; see, for example, Fig. S7 which shows an analogous experiment to that shown in Fig. 5, except using a feed gas composition of $31.0 \% \mathrm{CO}_{2}+69.0 \% \mathrm{Ar}$ and an input power of $14 \mathrm{~W}$ (when argon was employed in the feed, it was found that plasma was initiated and sustained at lower input power than when using $\mathrm{N}_{2}$, and the maximum power that could be employed was also lower); the 1150 and $1210 \mathrm{~cm}^{-1}$ features are clearly visible, growing with time. These features may be due to a transverse optical (TO) mode at $1210 \mathrm{~cm}^{-1}$ and a longitudinal optical (LO) mode at $1150 \mathrm{~cm}^{-1}$ of amorphous $\mathrm{SiO}_{2}$. These have previously been observed in the growth of thin films of $\mathrm{SiO}_{2}$ [41] and were observed on the high wavenumber side of the large $\mathrm{SiO}_{2}$ transverse optical peak due to the asymmetric stretch at $1070 \mathrm{~cm}^{-1}$. They are thought to be due to disorder-induced mode coupling in amorphous $\mathrm{SiO}_{2}$ with the exact positions varying dependent on conditions. In Lange's work [41] they were shown to be stronger with ion bombardment. Whilst very interesting, it is not clear that the species responsible for the 1150 and $1210 \mathrm{~cm}^{-1}$ features participate in the reduction of $\mathrm{CO}_{2}$ and hence are not relevant to the aim of this paper. Further work is in progress to elucidate this chemistry, and will be reported in a future publication.

Given the experimental uncertainties associated with the reflectance cell, and the fact that it is still under development, it is not possible to draw any meaningful, quantitative data from the spectra in Fig. 5: suffice to state that the production of $\mathrm{CO}_{2}^{*}$ fell from $92 \%$ of the $\mathrm{CO}_{2}$ in the feed gas after $2 \mathrm{~min}$ operation to $89 \%$ after $20 \mathrm{~min}$. However, the data in Fig. S4 strongly suggests that this decrease in the formation of $\mathrm{CO}_{2}^{*}$ was not reflected in an increase in the conversion to $\mathrm{CO}^{*}$.

The absence of any features due to the oxides of nitrogen in the various spectra discussed above is worthy of note, as such species have been observed in $\mathrm{CO}_{2}$ and $\mathrm{N}_{2}$ plasmas $[6,42]$ and the specific energy densities employed by these authors were comparable to those employed in the current work. The absence of such species may be due to catalytic activity of the Macor and/or differences in construction of the reactors leading to different electric fields and electron energies.

\section{The Thermally Driven Reaction of $\mathrm{CO}_{2}$ at Macor}

The uncatalysed thermolysis of $\mathrm{CO}_{2}$ into $\mathrm{CO}$ and $\mathrm{O}_{2}$ takes place at negligible rates at temperatures $<1500{ }^{\circ} \mathrm{C}$ but the process is catalysed by metal oxides such as $\mathrm{ZrO}_{2}, \mathrm{CeO}_{2}$ and mixed $\mathrm{Ce} / \mathrm{Zr}$ oxides such that thermolysis occurs at temperatures $>1200{ }^{\circ} \mathrm{C}$ [43].

Fig. S8 shows spectra collected from the Macor disc under nitrogen up to $600{ }^{\circ} \mathrm{C}$, showing only the spectra taken every $100{ }^{\circ} \mathrm{C}$, for clarity. As can be seen from the figure, the spectra are dominated by a structured, broad loss between 3000 and $1000 \mathrm{~cm}^{-1}$, the broad gain of an $\mathrm{O}-\mathrm{H}$ stretch with a maximum around $3360 \mathrm{~cm}^{-1}$, and sharp loss and gain features near $3700 \mathrm{~cm}^{-1}$ which may be attributed to isolated $\mathrm{O}-\mathrm{H}$ stretches [44].

Figure $6 \mathrm{a}-\mathrm{c}$ show the reflectance spectra collected in $23 \% \mathrm{CO}_{2}+77 \% \mathrm{~N}_{2}$ as a function of temperature up to $600{ }^{\circ} \mathrm{C}$ : Fig. 6 a shows all the spectra, Fig. $6 \mathrm{~b}$ the spectra up to $200{ }^{\circ} \mathrm{C}$ and Fig. $6 \mathrm{c}$ the spectra from 250 to $600{ }^{\circ} \mathrm{C}$. For comparison, Fig. S9 shows the spectrum 
Fig. 6 a In situ FTIR spectra $\left(8 \mathrm{~cm}^{-1}\right.$ resolution, 100 co-added and averaged scans, $60 \mathrm{~s}$ per scanset) collected from a $12.5 \mathrm{~mm}$ diameter Macor disc in a static atmosphere of $23 \%$ $\mathrm{CO}_{2}+77 \% \mathrm{~N}_{2}$ at the temperatures shown on the figure. The temperature was ramped at $5{ }^{\circ} \mathrm{C} \min ^{-1}$. The spectra in a up to b $200{ }^{\circ} \mathrm{C}$ and c 250 to $600{ }^{\circ} \mathrm{C}$
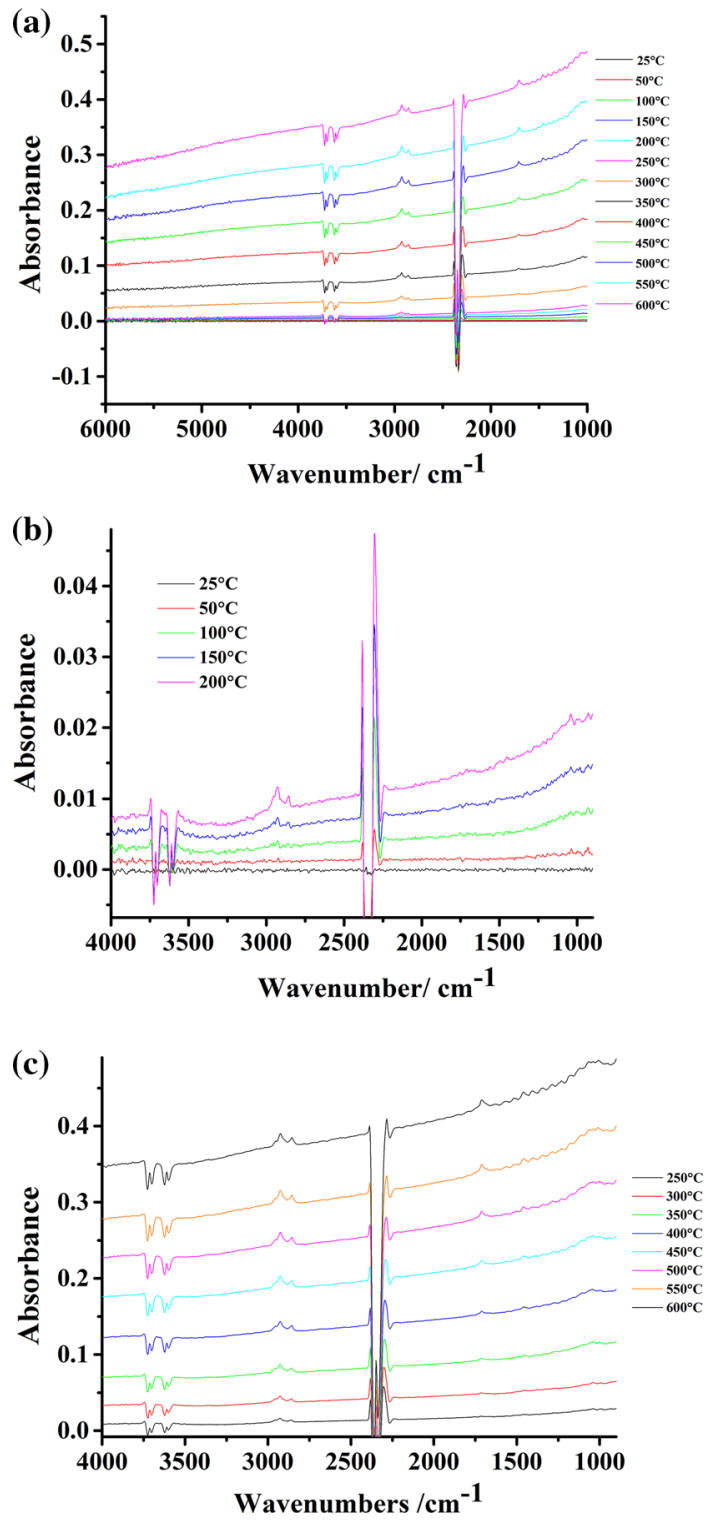

collected at $600{ }^{\circ} \mathrm{C}$ in Fig. S8 along with spectra collected at the same temperature in analogous experiments using $36 \% \mathrm{CH}_{4}+64 \% \mathrm{~N}_{2}$ and $21 \% \mathrm{CO}_{2}+43 \% \mathrm{CH}_{4}+36 \% \mathrm{~N}_{2}$, and Fig. 7 shows a plot of the absorbance at $2000 \mathrm{~cm}^{-1}$ in Fig. 6 a versus temperature. It is clear from Figs. 6a and 5 that a broad, intense background feature extends across the spectrum and increases towards longer wavelength. This is likely to be due to radiative emission from the Macor disc which increases with temperature. However, it depends strongly on the composition of the gas phase above the Macor: in $\mathrm{N}_{2}$ it is absent, it is intense and of equal intensity in $23 \% \mathrm{CO}_{2} / \mathrm{N}_{2}$ and $21 \% \mathrm{CO}_{2}+43 \% \mathrm{CH}_{4} / \mathrm{N}_{2}$, and present 
Fig. 7 A plot of the absorbance at $2000 \mathrm{~cm}^{-1}$ of the spectra in Fig. $6 \mathrm{a}$ as a function of temperature

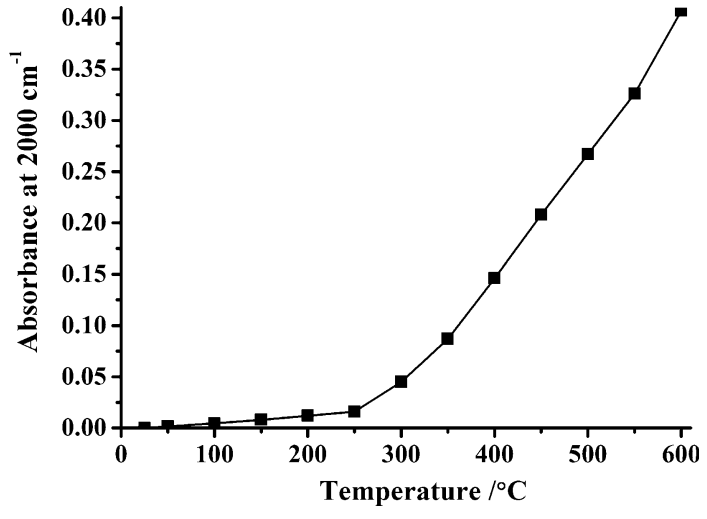

but of lower intensity in $36 \% \mathrm{CH}_{4} / \mathrm{N}_{2}$. Whilst extremely interesting, a discussion of these data are outwith the remit of this paper and will be presented in a subsequent submission.

Figure $6 \mathrm{a}-\mathrm{c}$ are dominated by the very intense $\mathrm{CO}_{2}$ loss features at 2360 and $2340 \mathrm{~cm}^{-1}$, and the $\mathrm{CO}_{2} / \mathrm{CO}_{2}^{*}$ combination bands between 3500 and $4000 \mathrm{~cm}^{-1}$ are also clearly seen, as are the structures due to the overlay of the asymmetric stretches due to the loss of $\mathrm{CO}_{2}$ and gain of $\mathrm{CO}_{2}^{*}$, see Fig. S10 which shows the spectrum collected at $100{ }^{\circ} \mathrm{C}$ in Fig. 6a, and Fig. S11 which compares the bands obtained in the thermal and plasma experiments directly. As expected, the $\mathrm{P}$ and $\mathrm{R}$ bands due to $\mathrm{CO}$ are absent from the thermal spectra and, given the noise on the spectra in Fig. $6 \mathrm{a}-\mathrm{c}$ is ca. $4 \times 10^{-4}$, this suggests the $\mathrm{CO}$ absorption at $2116 \mathrm{~cm}^{-1}$ must be $\leq 4 \times 10^{-4}$, hence $[\mathrm{CO}] \leq 1.2 \times 10^{-5}$ $\mathrm{M}$ and the conversion of $\mathrm{CO}_{2}$ to $\mathrm{CO}$ is $\leq 0.1 \%$, i.e. very low, as would be expected on the basis of the literature [41] and in complete contrast to the plasma experiments. The bands around $2900 \mathrm{~cm}^{-1}$ are due to the protective polymer film on the beam splitter of the spectrometer.

\section{Conclusions}

The combination of the FTIR reflectance and transmission plasma cells allowed reasonable estimations of the conversion of $\mathrm{CO}_{2}$ to $\mathrm{CO}$, and provided a direct method of assessing the temperature of the gases in the plasma glow using the broadening of the $\mathrm{CO}$ absorption. The conversion and energy efficiencies observed were comparable to those routinely reported in the literature, giving confidence in the approach. Further, and for the first time, the same chemical system was studied driven both by plasma and thermally, and the data compared and contrasted: whilst up to $9 \%$ conversion of the $\mathrm{CO}_{2}$ to $\mathrm{CO}$ was observed in the plasma experiments, no conversion was observed in the thermal experiment up to $600{ }^{\circ} \mathrm{C}$. Finally, strong plasma-induced absorptions were observed on the Ti/Macor which remained for some time after the plasma was stopped which remain unassigned, but have been tentatively attributed to transverse and longitudinal optical modes of $\mathrm{SiO}_{2}$ and work is continuing to obtain definitive identification of these and the implications of their formation.

In summary, we believe the experimental methodology described has significant potential to elucidate the chemistry taking place in non-thermal plasma catalysis and hence provide the paradigm shift required to take the technology forward to commercial reality. 
Acknowledgements Abd Halim Bin Md Ali would like to thank the Government of Malaysia for a scholarship to study for a Ph.D., the staff of the Majlis Amanah Rakyat in Kuala Lumpur, Malaysia and London, United Kingdom for their invaluable assistance. Z. T. A. W. Mashhadani would like to thank the Government of Iraq for a scholarship, the staff of the Higher Committee for Education Development in Iraq for their invaluable assistance and the Iraq Ministry of Oil Petroleum Research and Development Center PRDC for the opportunity to study for a Ph.D. The authors also wish to thank Mr. Neville Dickman and Mr.

$\mathrm{S}$. Daley for their assistance and support for this work.

Open Access This article is distributed under the terms of the Creative Commons Attribution 4.0 International License (http://creativecommons.org/licenses/by/4.0/), which permits unrestricted use, distribution, and reproduction in any medium, provided you give appropriate credit to the original author(s) and the source, provide a link to the Creative Commons license, and indicate if changes were made.

\section{References}

1. Whitehead JC (2016) Plasma-catalysis: the known knowns, the known unknowns and the unknown unknowns. J Phys D Appl Phys 49:243001

2. Aerts R, Martens T, Bogaerts A (2012) Influence of vibrational states on $\mathrm{CO}_{2}$ splitting by dielectric barrier discharges. J Phys Chem C 116:23257-23273

3. Fridman A (2008) Plasma chemistry. Cambridge University Press, New York

4. Fridman AA, Rusanov VD (1994) Theoretical basis of non-equilibrium near atmospheric pressure plasma chemistry. Pure Appl Chem 66:1267-1278

5. Chen HL, Lee HM, Chen SH, Chang MB (2008) Review of packed-bed plasma reactor for ozone generation and air pollution control. Ind Eng Chem Res 47:2122-2130

6. Snoeckx R, Heijkers S, Van Wesenbeeck K, Lenaerts S, Bogaerts A (2016) $\mathrm{CO}_{2}$ conversion in a dielectric barrier discharge plasma: $\mathrm{N}_{2}$ in the mix as a helping hand or problematic impurity? Energy Environ Sci 9:999-1011

7. Aerts R, Somers W, Bogaerts A (2015) Carbon dioxide splitting in a dielectric barrier discharge plasma: a combined experimental and computational study. Chemsuschem 8:702-716

8. Jeong JY, Park J, Henins I, Babayan SE, Tu VJ, Selwyn GS et al (2000) Reaction chemistry in the afterglow of an oxygen-helium, atmospheric-pressure plasma. J Phys Chem A 104:8027-8032

9. Martin PA, Guelachvili G (1990) Velocity-modulation Fourier-transform spectroscopy of molecular ions. Phys Rev Lett 65:2535

10. Benidar A, Guelachvili G, Martin PA (1991) Selective detection of OH radical in emission by concentration-modulation infared FTS. Chem Phys Lett 177:563-567

11. Zhang S, van Gaens W, van Gessel B, Hofmann S, van Veldhuizen E, Bogaerts A, Bruggeman P (2013) Spatially resolved ozone densities and gas temperatures in a time modulated RF driven atmospheric pressure plasma jet: an analysis of the production and destruction mechanisms. J Phys D Appl Phys 46:205202

12. Schmidt-Bleker A, Winter J, Iseni S, Dünnbier M, Weltmann KD, Reuter S (2014) Reactive species output of a plasma jet with a shielding gas device - combination of FTIR absorption spectroscopy and gas phase modelling. J Phys D Appl Phys 47:145201

13. Al-Abduly A, Christensen P (2015) An in situ and downstream study of non-thermal plasma chemistry in an air fed dielectric barrier discharge (DBD). Plasma Sources Sci Technol 24:065006

14. Rivallan M, Fourré E, Aiello S, Tatibouët JM, Thibault-Starzyk F (2012) Insights into the mechanisms of isopropanol conversion on $\gamma$-A12O3 by dielectric barrier discharge. Plasma Process Polym 9:850-854

15. Rodrigues A, Tatibouët JM, Fourré E (2016) Operando DRIFT spectroscopy characterization of intermediate species on catalysts surface in VOC removal from air by non-thermal plasma assisted catalysis. Plasma Chem Plasma Process 36:901-915

16. Stere CE, Adress W, Burch R, Chansai S, Goguet A, Graham WG, Hardacre C (2015) Probing a nonthermal plasma activated heterogeneously catalyzed reaction using in situ DRIFTS-MS. ACS Catal 5:956-964

17. Jia Z, Rousseau A (2016) Sorbent track: quantitative monitoring of adsorbed VOCs under in situ plasma exposure. Sci Rep 6:31888

18. Nair SA, Nozaki T, Okazaki K (2007) In situ Fourier transform infrared (FTIR) study of nonthermalplasma-assisted methane oxidative conversion. Ind Eng Chem Res 46(11):3486-3496 
19. Amouroux J, Cavadias S, Doubla A (2011) Carbon dioxide reduction by non-equilibrium electrocatalysis plasma reactor. In: IOP conference series: materials science and engineering, vol 19, no 1 . IOP Publishing, p 012005

20. http://www.precision-ceramics.co.uk/wp-content/uploads/2016/04/macor-brochure-english.pdf

21. Bevy LP (2006) Trends in catalysis research. Nova Publishers, New York

22. Christensen PA, Jones SWM (2014) An in situ FTIR study of undoped polybenzoimadazole as a function of relative humidity. Polym Degrad Stab 105:211-217

23. Bolis V, Fubini B, Garrone E, Morterra C (1989) Thermodynamic and vibrational characterization of $\mathrm{CO}$ adsorption on variously pretreated anatase. J Chem Soc Faraday Trans 1 Phys Chem Condens Phases 85:1383-1395

24. Herzberg G (1945) Molecular spectra and molecular structure. Vol. 2: infrared and Raman spectra of polyatomic molecules, by G. Herzberg. Van Nostrand, Reinhold, New York, p 272

25. Stein SE "Infrared Spectra", NIST Chemistry WebBook. In: Linstrom PJ, Mallard WG (eds) NIST Standard Reference Database Number 69. National Institute of Standards and Technology, Gaithersburg MD, 20899. http://webbook.nist.gov. Retrieved February 17, 2017

26. Plyler EK, Blaine LR, Tidwell ED (1955) Infrared absorption and emission spectra of carbon monoxide in the region from 4 to 6 microns. J Res NBS 55:183-189

27. Bennett CJ, Jamieson CS, Kaiser RI (2010) Mechanistical studies on the formation and destruction of carbon monoxide $(\mathrm{CO})$, carbon dioxide $\left(\mathrm{CO}_{2}\right)$, and carbon trioxide $\left(\mathrm{CO}_{3}\right)$ in interstellar ice analog samples. Phys Chem Chem Phys 12:4032-4050

28. Herzberg G Molecular spectra and molecular structure. Vol. 1: infrared and Raman spectra of diatomic molecules, 2nd edn. Van Nostrand, Reinhold, New York, p 950

29. Bauerecker S, Taraschewski M, Weitkamp C, Cammenga HK (2001) Liquid-helium temperature longpath infrared spectroscopy of molecular clusters and supercooled molecules. Rev Sci Instrum $72: 3946-3955$

30. Herzberg G (1950) Molecular spectra and molecular structure: I spectra of diatomic molecules, 2nd edn. Van Nostrand, New York, pp 126-127

31. Gordillo-Vázquez FJ (2008) Air plasma kinetics under the influence of sprites. J Phys D Appl Phys 41:234016

32. Rond C, Bultel A, Boubert P, Chéron BG (2008) Spectroscopic measurements of nonequilibrium $\mathrm{CO}_{2}$ plasma in RF torch. Chem Phys 354:16-26

33. Richard J (2011). In: 49th AIAA aerospace sciences meeting including the new horizons forum and aerospace exposition, Orlando, Florida, 4 January 2011, American Institute of Aeronautics and Astronautics, pp 2011-447

34. Moore CE (1949) Atomic energy levels. Circular of NBS 467

35. Chase MW (1998) NIST-JANAF thermochemical tables (journal of physical and chemical reference data monograph no. 9). American Institute of Physics 1790

36. Hunt J, Ferrari A, Lita A, Crosswhite M, Ashley B, Stiegman AE (2013) Microwave-specific enhancement of the carbon-carbon dioxide (Boudouard) reaction. J Phys Chem C 117:26871-26880

37. Manley TC (1943) The electric characteristics of the ozonator discharge. Trans Electrochem Soc 84:83-96

38. Wang JY, Xia GG, Huang A, Suib SL, Hayashi Y, Matsumoto H (1999) $\mathrm{CO}_{2}$ decomposition using glow discharge plasmas. J Catal 185:152-159

39. Zheng G, Jiang J, Wu Y, Zhang R, Hou H (2003) The mutual conversion of $\mathrm{CO}_{2}$ and $\mathrm{CO}$ in dielectric barrier discharge (DBD). Plasma Chem Plasma Process 23(1):59-68

40. Snoeckx R, Bogaerts A (2017) Plasma technology-a novel solution for $\mathrm{CO}_{2}$ conversion? Chem Soc Rev 46:5805-5863

41. Lange $\mathrm{P}$ (1989) Evidence for disorder-induced vibrational mode coupling in thin amorphous $\mathrm{SiO}_{2}$ films. J Appl Phys 66:201-204

42. Xu S, Whitehead JC, Martin PA (2017) $\mathrm{CO}_{2}$ conversion in a non-thermal, barium titanate packed bed plasma reactor: the effect of dilution by Ar and $\mathrm{N}_{2}$. Chem Eng J 327:764-773

43. Jiang Q, Chen Z, Tong J, Yang M, Jiang Z, Li C (2017) Direct thermolysis of $\mathrm{CO}_{2}$ into CO and $\mathrm{O}_{2}$. Chem Commun 53:1188-1191

44. Christensen PA, Attidekou PS, Egdell RG, Maneelok S, Manning DAC (2016) An in situ FTIR spectroscopic and thermogravimetric analysis study of the dehydration and dihydroxylation of $\mathrm{SnO}_{2}$ : the contribution of the (100), (110) and (111) facets. Phys Chem Chem Phys 18:22990-22998 